\title{
The impact of alcohol consumption on homicide : A time-series analysis of three Nordic countries
}

\section{Lehti, Martti Mikael}

2020-05-01

Lehti , M M \& Sirén , R 2020 , ' The impact of alcohol consumption on homicide : A time-series analysis of three Nordic countries ' , European Journal of Criminology , vol. 17 , no. 3 , pp. 352-369 . https://doi.org/10.1177/1477370818802524

http://hdl.handle.net/10138/327052

https://doi.org/10.1177/1477370818802524

unspecified

acceptedVersion

Downloaded from Helda, University of Helsinki institutional repository.

This is an electronic reprint of the original article.

This reprint may differ from the original in pagination and typographic detail.

Please cite the original version. 
Martti Lehti and Reino Sirén

The impact of alcohol consumption on homicide: a time-series analysis of three Nordic countries

Corresponding author:

Dr. Martti Lehti

Senior researcher

Institute of Criminology and Legal Policy

University of Helsinki

P.O.Box 24

00014 Helsingin yliopisto, Finland

Phone: +358503245116

Fax:

E-mail: martti.lehti@helsinki.fi

Word count (including abstract, key words, tables and figures, excluding title page): 7,780 words

Martti Lehti. LL.D., Senior Researcher, Institute of Criminology and Legal Policy, University of Helsinki, Unioninkatu 40, 00014 Helsingin yliopisto. E-mail: martti.lehti@helsinki.fi; Phone: +358 503245116.

Reino Sirén. Senior Research Analyst (retired), Institute of Criminology and Legal Policy, University of Helsinki, Lohenpyrstö 2 A, 00650 Helsinki, E-mail: reino.siren@kolumbus.fi.

Authors have contributed equally to this study and are listed in alphabetic order. 
Abstract

The article explores the statistical association between annual alcohol consumption and homicide mortality in Finland, Sweden and Norway from the early 19th century to 2013. The results show statistically significant impacts on overall and on male homicide mortality in Finland and on male homicide mortality in Sweden. In Norway, we found no significant impacts. The results suggest that changes in the level of alcohol consumption have had a stronger impact on homicide rate in Finland, characterized by a heavier drinking culture, than in Norway or Sweden. The strength of the association between alcohol consumption and homicide levels seems also to vary in time and to be conditioned by economic and socio-political factors.

Key words: Alcohol, homicide, time-series, Nordic countries, Finland 


\section{Introduction}

Alcohol has a prominent role in crimes of violence in many societies where it is a culturally accepted drug (Bye, 2012). Numerous studies at the individual-level indicate an association between alcohol intoxication and violence. For example, Bye's (2012), Rossow's (2001) and Pernanen's (1981) studies and reviews include extensive summaries on this topic. Their main conclusion is that explanations of the connection are many and vary considerably. However, the mechanisms of the connection have little relevance at the community level (and, for example, on social policies) if the level of alcohol consumption is per se a determinant of violent crime rates (Rossow, 2001; Bye, 2012). In this case, the regulation of total consumption of alcohol would be a simple and efficient tool for preventing violent crimes.

Cross-sectional evidence for this hypothesis is contradictory. This also applies to the most aggravated type of human violence - homicides. Globally, absolute alcohol consumption levels seem not to have any link with regional homicide rate differences (Lappi-Seppälä and Lehti, 2015). In Europe, however, drinking pattern related factors seem to influence regional differences in homicide rates. The regions where binge drinking dominates consumption have often a closer association between violent crime and alcohol drinking than the regions where alcohol is consumed mainly in the context of meals (Rossow, 2001; Pridemore, 2002; Bye, 2006). An ideal place to search for an association between total consumption and homicide rate levels would be a region where alcohol is a generally accepted drug and where overall homicide rates are low; i.e. where alcohol can potentially influence interpersonal violence levels and at the same time, the influence of other possible factors is probably moderate or even negligible. Thus, Europe would be a good place in which to search for such an association. On the continent, alcohol is a culturally accepted drug and is widely consumed by all population groups; on the other hand, European homicide rates are today extraordinary low in the global context (Lappi-Seppälä and Lehti, 2015). Even a weak 
statistical association between alcohol consumption and homicide rates would probably be easier to find in Europe than in other parts of the world.

The association observed in earlier studies in Europe seems not to be related directly to consumption levels but mainly to those in drinking patterns. Alcohol and homicidal crime seem to have the closest association in countries belonging to the so-called vodka zone in the northern and the eastern parts of the continent where binge drinking and hard liquors have historically characterized alcohol consumption. In this region, the closeness of the association seems to apply to both countries with low and high overall homicide rates (Rossow, 2001; Pridemore, 2002; Bye, 2006).

Three Nordic countries, Finland, Norway, and Sweden have historically been part of the vodka zone and have had a high percentage of homicides perpetrated in situations involving alcohol drinking. They are also among the European countries with long and relatively reliable statistical data series on annual alcohol consumption, perpetrated homicides and resident population. From all three Nordic countries, we have scattered statistical data on the intoxication of homicide offenders from the 18th century onwards. During the last two centuries, the role of alcohol in homicides has not been constant in any of the three. The percentage of intoxicated offenders has varied in Norway between 40 to 75 per cent (Drap i Norge, 2010; Bye 2012; Nasjonal drapsoversikt, 2014), in Sweden between 40 to 70 per cent (Lindqvist, 1986; Lenke, 1990; Jansson, 1998; Kaspersson, 2000; Rying, 2000; Granath et al., 2011), and in Finland between 60 to 80 per cent (Lehti, 2001; Kivivuori and Lehti, 2011; Lehti and Kivivuori, 2011; Lehti, 2017). On the other hand, the variation of the percentage of alcohol-related homicides seems to have been similar in all three countries. The highest percentages have coincided with periods of relatively high homicide rates and the lowest ones with periods of low homicide rates (Kivivuori and Lehti, 2011). This indicates that the rates of alcohol-related homicides have been more volatile than homicide rates on average and may have played a role in the variations of the overall homicide rate. 
The large relative and absolute numbers of alcohol-related homicides probably explains why a considerable part of the global research of the community level association between alcohol consumption and homicide levels originates from Scandinavia. The Finnish criminologist Veli Verkko $(1948,1951)$ was one of the first who researched the association extensively in his comparative studies in the 1920s and 1930s. In more recent decades, Lenke (1990) and Norström (1998) have studied the statistical association between changes in the total alcohol consumption and homicide rates in Sweden. Rossow $(2001,2004)$ and Bye (2008) have explored the association in the Scandinavian countries and elsewhere in Europe and in North America, as have some local scholars (Parker and Cartmill, 1998; Pridemore and Chamlin, 2006).

These studies, which cover different periods of the 20th century, have found a statistically significant association between the annual changes of the total alcohol consumption and homicide rates in some but not in all the studied countries. In the countries where the association exists, it often concerns only male homicide mortality. They suggest that the differences between drinking cultures may influence the strength of this association and that the alcohol effect is strongest in cultures with the most hazardous drinking patterns (Rossow, 2001; Bye, 2012).

\section{The Object of this Study}

We analyze the association between alcohol consumption and homicide levels in Finland, Norway and Sweden from the early 19th century until 2013.

We think that this kind of comparative analysis is reasonable. First, homicide rates have differed markedly in these countries in the last two centuries, the Finnish rate has been about double of that in Norway and Sweden (Verkko, 1948; Verkko, 1951; Ylikangas, 1976; Kivivuori and Lehti, 2011). This difference is remarkable since the three countries share historical roots and have had similar socio-political societal structures during the period. Finnish homicide research has often explained the higher homicide rates in Finland by a more intoxication oriented drinking culture (Verkko, 1951; Kivivuori and Lehti, 2011; Granath et al., 2011). Second, earlier research has found in all 
three countries a statistically significant association between the annual changes of the total alcohol consumption and violent crime levels, including assaults (except Rossow, 2001, see below).

We think that we can draw more reliable conclusions about the association between alcohol consumption and homicide levels when we study the association simultaneously in all three countries using the same analysis method. Moreover, many of the earlier studies have used registered assault crimes or assault crime convictions as the main indicator of violence. We think that homicide mortality is a more reliable indicator of long-term trends in violence because it is less susceptible to changes in the tolerance towards violence, the rate of detection, and the registration of crimes (Aebi and Linde, 2012; Spierenburg, 2012). On the other hand, homicides are very rare events compared to assaults. (During the studied period, the average annual number of homicide victims (excluding infants and outlier years) was in Finland 102, in Sweden 58, and in Norway only 20.) Unique interpersonal factors play a prominent role in their occurrence. Unlike in more common crimes like assaults, it is far less obvious that changes in the level of total alcohol consumption would also have a discernible effect, even a weak one, on the number of homicides. Our study also has a substantially longer time frame than earlier Nordic studies, and covers the change in all three countries from pre-industrial to post-industrial societies (Lenke, 1990; Hauge, 1991; Norström, 1998; Skog and Björk, 1998; Rossow, 2001; Sirén, 2002). The use of long time-series in the analysis increases the possibility of an adequate model identification, estimation and hypothesis testing (Rehm and Gmel, 2001). Long time-series also allow us to explore the invariance of the association - a question that we think earlier research has overlooked. The association between alcohol consumption and homicide levels is not necessarily constant over time.

In the analysis, we have used time-series ARIMA modelling. A special feature in our analysis is that we take into account the presence of possible outlying observations in the homicide data. The long time frame includes several epochs with considerable increases in homicide rates. This holds especially for Finland but cannot be overlooked for Norway or Sweden either. Most notably such deviant historical periods coincide with political crises, wars or foreign military occupations. It is 
probable that the increases in homicide rates in these periods are related to other factors than changes in alcohol consumption. Therefore, in order to test reliably the connection between the total alcohol consumption and homicide levels, it is important to control the effect of such exceptional periods.

To sum up, we have looked for answers to the following questions: 1) Have the annual changes in homicide mortality been associated with changes in alcohol consumption in Finland, Sweden and Norway from the 19th century until today? 2) Is there evidence that the association between alcohol consumption and homicide levels has differed between these countries? 3) Has the association changed over the course of time in Finland?

Based on earlier studies (Rossow, 2001; Pridemore, 2002; Bye, 2008), our main hypothesis is that the annual number of homicides in Finland has been more sensitive to changes in alcohol consumption than in the other Nordic countries due to the historically heavier drinking habits of Finns (Verkko, 1951; Mäkelä, 1986; Gmel et al., 2001; Mäkelä et al., 2001; Kuntsche et al., 2004).

\section{Data}

We have used homicide mortality (excluding infanticides) as the violence indicator and either total per capita retail alcohol consumption (Norway, Sweden) or total per capita alcohol consumption (Finland) as the alcohol indicator. 
Table 1. Basic statistical information about the homicide and alcohol consumption time-series used in this study (excluding outlier years)

\begin{tabular}{|c|c|c|c|}
\hline & $\begin{array}{l}\text { Finland } \\
(1802-2013)\end{array}$ & $\begin{array}{l}\text { Norway } \\
(1861-2013)\end{array}$ & $\begin{array}{l}\text { Sweden } \\
(1861-2013)\end{array}$ \\
\hline \multicolumn{4}{|l|}{ Homicides } \\
\hline annual number of victims, mean & 102 & 20 & 58 \\
\hline annual number of victims, range & $11-359$ & $3-64$ & $22-126$ \\
\hline annual mortality per 100,000 pop., mean & 3.36 & 0.59 & 0.87 \\
\hline annual mortality per 100,000 pop., range & $1.21-10.45$ & $0.16-1.54$ & $0.35-1.73$ \\
\hline \multicolumn{4}{|l|}{ Alcohol consumption } \\
\hline litres per capita per year, mean & 4.2 & 4.3 & 4.6 \\
\hline litres per capita per year, range & $0.7-10.5$ & $1.1-6.9$ & $0.8-7.5$ \\
\hline
\end{tabular}

\section{Homicides}

For Finland and Sweden, cause of death (COD) data of homicide mortality are available from the 1750s onwards (Verkko, 1948; von Hofer, 2011; Kivivuori and Lehti, 2011; Koskivirta, 2014). In Norway, COD data are available from 1836 onwards but with substantial gaps. We have excluded from our data infanticides and, in Norway, Holocaust and combat victims from the period 19401945 (Figure 1).

The comparability of the Nordic COD statistics is good (Kivivuori and Lehti, 2011). However, in none of the countries are the data fully comparable throughout the entire period. Finnish studies report that the number of homicides prosecuted in the criminal courts was about 50 per cent higher than the number of homicide victims in the COD statistics in the early 19th century (Verkko, 1951; Ylikangas, 1976; Sirén, 1995). During the century, the difference grew smaller and disappeared from the 1880s onwards (Vuorela, 2014). The situation in Sweden and Norway was probably similar. There is, however, no evidence that different types of homicide would have been registered differently and the data should not be biased in this respect. We have converted homicide mortality data to annual mortality rates per 100,000 inhabitants. One should note that in Norway and Finland the populations were less than two million during most of the 19th century causing relatively large annual fluctuations in the number of homicides. 


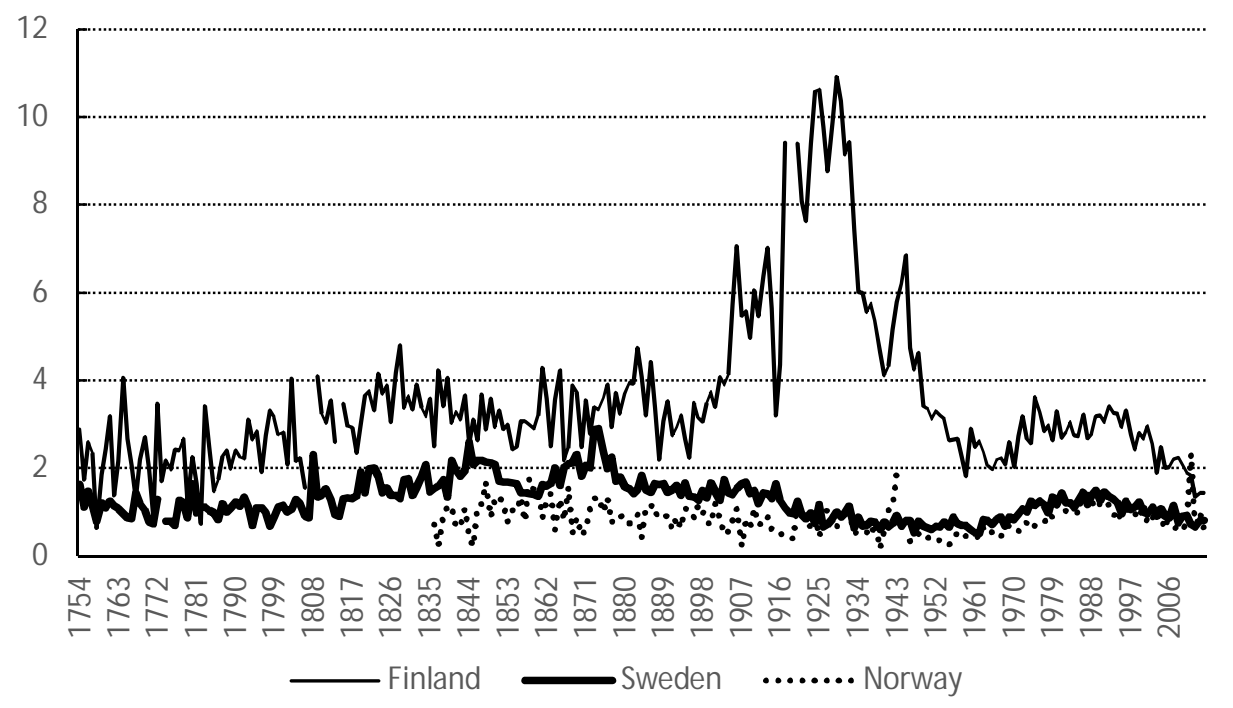

Figure 1. Homicide mortality (victims per 100,000 inhabitants) in Finland, Sweden and Norway, 1754-2013 (Finland excl. 1808, 1918-19; Norway excl. 1944-45) (von Hofer and Lappi-Seppälä, 2014)

\section{Homicide Trends}

Homicide mortality rates were constantly higher in Finland than in Sweden or Norway during the studied period (Figure 1). In all three countries, longer- and shorter-term fluctuations characterized the trends. These fluctuations were generally similar in Sweden and Norway (with the exception of the peak that occurred in Norway during the German occupation in the 1940s). In Finland, the trend differed sharply from the other two from the mid-19th century to the 1950s. This difference was especially marked in the 1905-1948 era. The homicide wave in Finland during that era has been linked to the violent process of becoming independent and the peculiarities of industrialization in the country (Lehti 2001). The period began with a constitutional conflict with Russia and the gradual eroding of the Finnish autonomy. It included two revolutions (1905 and 1917), the gaining of independence (December 1917), followed by an attempted coup d'état by the Social Democratic Party and a civil war in the spring of 1918, as well as several smaller armed conflicts with the Soviet-Russia in 1918-1922. The civil war and its repercussions left deep wounds in Finnish society making the 1920 s and 1930 s both politically and socially turbulent. The period ended in the Second World War that lasted in Finland from November 1939 (when the Soviet Union attacked the country) until September 1947 (when the Allied Control Commission left and Finland regained its 
full sovereignty). Since the Second World War the homicide mortality trend in Finland has resembled those in Sweden and Norway (Figure 1). Thus, under peacetime conditions, homicide trends have been rather similar across the three studied Nordic countries. On the other hand, in terms of mere mortality levels and level changes, wars and social crises seem to have dominated the dynamics of homicide mortality in the 19th and 20th century Finland and to some extent in Norway, too. In Sweden the crises element was missing during the studied era.

\section{Alcohol Consumption}

Swedish and Norwegian alcohol consumption data have been obtained from official statistics of registered retail consumption (Figure 2) (Drogutvecklingen i Sverige, 2010; Drogutvecklingen i Sverige, 2014; Statistics Norway, 2016). The data of these two countries cover the years from mid1800s until 2013.

In Finland, our data on alcohol consumption start from 1802. We have used the data series on total consumption compiled in the Institute of Criminology and Legal Policy from several sources (Figure 2). Our earliest information era $1802-1889$ is based on alcohol-related mortality statistics (from 1878 onwards referring to ethanol-poisoning mortality) published by Turpeinen $(1975,1977)$ and his estimations of per capita consumption according to that data. For the 1890-1919 period we have used a time-series based on national alcohol production and customs data adjusted by Turpeinen's information about unregistered consumption (Ignatius, 1885; Suomen taloushistoria, 1983; Suomen tilastollinen vuosikirja, 1916; Suomen tilastollinen vuosikirja, 1921). Production statistics and Turpeinen's mortality data overlap for the years 1866-1917. The synchronous raw correlation of the two series is 0.86 indicating that the time-series constructed by Turpeinen is an acceptable proxy for annual changes in alcohol consumption from 1866 onwards. We have assumed that this is the case also before 1866 . We have not found any information that would contradict this assumption. The years 1919-1932 were prohibition years in Finland and official consumption statistics exist only of registered "medical" consumption that made up less than $20 \%$ of total 
consumption (Rasinaho, 2006). However, there exist several estimates of total consumption in the beginning of the prohibition (1919), in the mid-1920s and at the end of the prohibition (in the early 1930s). All of them are based on the annual volumes of confiscated smuggled alcohol and the registered alcohol sales (Lehti, 2001; Rasinaho, 2006; Kaartinen, 2012). We have used a linear trend between 1919, 1925 and 1932 of which estimates are available. The linear increasing trend is supported by published statistics on drunkenness arrests during the period (Lehti, 2001). Data of 1933-2013 have been obtained from the official consumption statistics and refer to total consumption. We have converted the retail consumption of 1933-1959 into total consumption by a conversion factor of 1.3 based on estimates of unregistered consumption in the early $1960 \mathrm{~s}$ (Päihdetilastollinen vuosikirja, 2010). (The proportion of unregistered consumption in the 1930s was probably higher but because we have analyzed annual changes in consumption level, this should not be a confounding problem.) Annual changes in unregistered consumption have been moderate since 1960 (Jääskeläinen, 2011; Varis and Virtanen, 2016). We have converted consumption data to per capita consumption of pure alcohol.

To sum up, the Finnish data of 1890-1919 and 1933-2013 are based on published official consumption statistics and their reliability and validity is comparable to those of the Swedish and Norwegian statistics. In addition, we can check the reliability of the cause-of-death data based timeseries for 1802-1889 (1917) by comparing it with official consumption statistics from 1866 onwards. The high positive correlation between these two independent overlapping time-series indicates strongly that we can use the Turpeinen's consumption time-series without major problems as an extension of the official consumption time-series from 1890 backwards. The problematic era is 1920-1932. Although the consumption estimates of these years are based on measurable statistical facts (confiscations and arrests), their numbers have not been determined by the changes in consumption levels only but also, for example, by those in the resources and tactics of the police and customs authorities. 
A problem concerning the registered retail consumption statistics of all three countries is unregistered consumption. A substantial proportion of alcohol consumption in Scandinavia is unregistered, and this proportion has varied over time (Lenke, 1990; Skog and Björk, 1998; Österberg, 2000; Arnberg and Lord, 2009). In this analysis, the problem concerns especially the Swedish and Norwegian data based on unmodified retail consumption. This means that in general, there is measurement error in the level of the used series. During the studied period, new restrictions in registered consumption have probably increased and any liberalization of controls decreased unregistered consumption. It is plausible that the trends of registered and unregistered consumption have diverged for some time-periods. However, as explained later, because we are working with differenced time-series and analyze annual changes in alcohol consumption (like e.g. Rossow (2001) and Bye (2007)), any trends in the time-series are filtered in the ARIMA estimation process. Thus, we can assume that even in the case of diverging trends, the measurement error in the annual changes of consumption remains nearly constant over a lengthy period of time and does not pose a serious source of error in testing the existence of the association between alcohol consumption and homicide levels. In addition, according to Rossow (2001), in Norway and Sweden there is no indication of any significant correlation in annual changes in recorded and unrecorded consumption in the second half of the 20th century, supporting the assumption that the usage of only recorded consumption does not seem to cause a significant bias. 


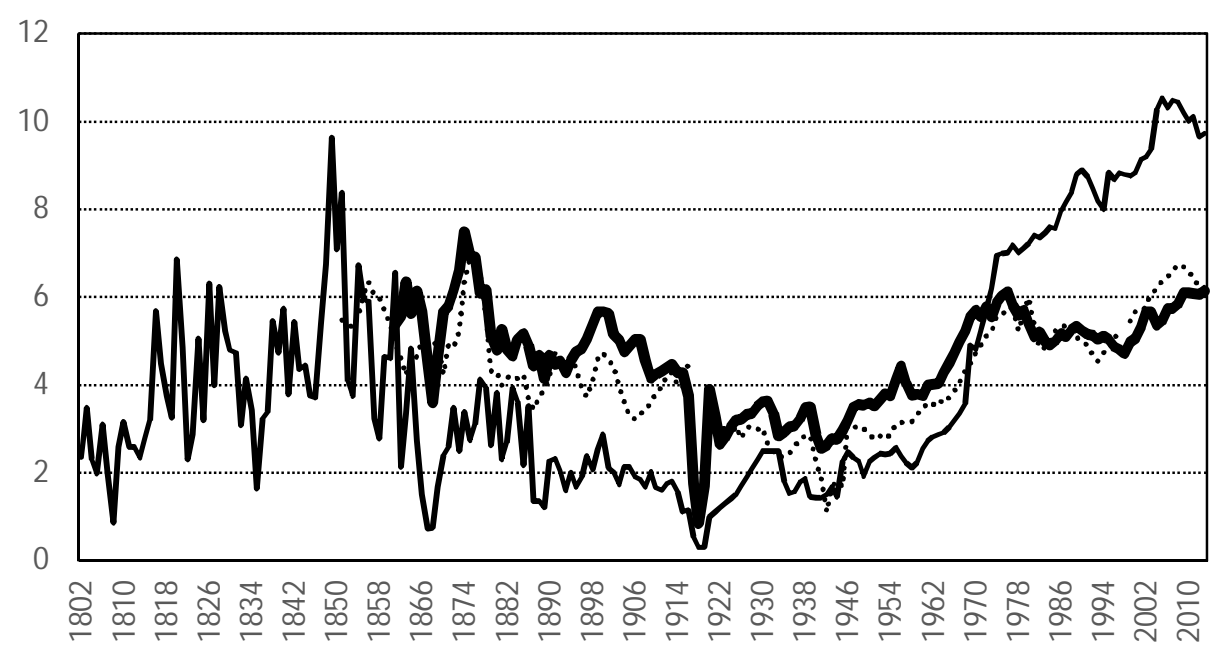

- Finland Sweden ......... Norway

Figure 2. Alcohol consumption (litres of pure alcohol per capita) in Finland, Sweden, and Norway, 18022013

\section{Alcohol Consumption Trends}

The general pattern of alcohol consumption trends were similar for all three countries during the studied era. Basic consumption levels of the 19th century were relatively high with a decreasing trend during the latter half of the century. The consumption was at its lowest during the first half of the 20th century and began to increase sharply in the second half. It should be noted that until the beginning of the1970s the consumption level was clearly lower in Finland than in Sweden and even lower than in Norway. The first occasion that Finnish consumption rose over the two other countries was in the 1970s and it continued to increase until the 2010s. In Sweden and Norway, the consumption levels have been relatively stable since the early 1970 s.

\section{Methods}

Our analysis is based on time-series ARIMA modelling. After examining the overall characteristics of the homicide mortality and alcohol consumption time-series, we specified an acceptable univariate ARIMA model for each homicide series. In specification of these models we examined the sample autocorrelation and sample partial autocorrelation functions (SACF and SPACF) of the 
time-series. The purpose of the ARIMA model building is to transform the, presumably autocorrelated, observed series into a structureless white noise process (Mills, 1990) by filtering all temporal regularity (trends, drift and autocorrelation) in the homicide series that would confound the testing of the association between alcohol consumption and homicide levels. The use of long time-series in the analysis increases the possibility of an adequate model identification, estimation and hypothesis testing (Rehm and Gmel, 2001).

Outlying observations, level shifts and structural changes have an adverse role in time-series analysis. First, outliers may cause serious biases in SACF and SPACF statistics, thus jeopardizing their usefulness as tools for model identification (Mills, 1990). Second, outliers in the homicide data may bias the estimated coefficients that describe the response of homicide rate to the change in alcohol consumption. In order to eliminate their effects, it is necessary to detect the time that outliers occurred, identify their type and estimate a model in which the different types of outliers are appropriately incorporated (Peña, 2010). Although we could base our decisions on historical evidence, we used automatic detection methods for this task to avoid subjectivity (Gómez and Maravall, 2010). Our statistical analysis program (SPSS 22) provided this option. First, we estimated 'noise-outlier' models for the homicide series, which in addition to the ARIMA parameters include parameters that account for the effects of outliers. Then we added alcohol consumption series as exogenous explanatory variables to these models. Thus, in the estimation of the alcohol consumption-homicide relation we fixed the type of the noise models (the order of autoregressive and moving average parts) and the time and type of outliers in homicide series. Formally, the models are simple transfer function-noise models where alcohol consumption is the independent input series and homicide time-series is the dependent response time-series (Mills, 1990).

Aggregate alcohol studies have employed additive (e.g. Norström, 1998; Sirén, 2002), semilogaritmic (e.g. Parker and Cartmill, 1998; Skog and Björk, 1998; Rossow, 2001) or both specifications (e.g. Lenke, 1990; Rossow, 2004; Bye, 2007) in modelling the alcohol-violence 
association. In semi-logaritmic models, the dependent variable is log-transformed, which corresponds to the assumption that the effect of alcohol is relative (Bye, 2007). The strait out logtransformation has been criticized on both interpretative and statistical grounds (Rehm and Gmel, 2001). In our analysis in specifying the models we have applied the principle of parsimony and assumed the simplest functional form between alcohol consumption and homicide rate, i.e. that it is additive and contemporaneous (Rehm and Gmel, 2001). To be able to compare our results with those of Rossow (2001), we have, however, also used semi-logaritmic modeling for the analysis of male homicide mortality in 1951-2013.

\section{Results}

First, we analyzed the Finnish data. The data on alcohol consumption in Finland are available from 1802 onwards. The series (years 1802-2013, n=212) exhibited drifting behaviour or waves of upward and downward trends. There was a significant autocorrelation in the series even when the automatic outlier detection was activated. This indicated that the series was non-stationary and had to be differenced. After differencing, the SACF and SPACF of the series suggested an ARIMA $(0,1,1)$ model with nine outliers. This outlier-noise model had no significant residual autocorrelation and the model could be accepted $(\mathrm{Q}(18) ; \mathrm{Sig} .=0.308)$. The nine detected outliers matched well with notable historical events (Table 2).

We also specified ARIMA models separately for male and female homicide mortality. For both a noise model of type $(0,1,1)$ was acceptable. After filtering no residual autocorrelation was present $(\mathrm{Q}(18)$; males Sig. $=0.739$, females Sig. $=0.307)$. In the male homicide series we detected 10 outliers. With few exceptions these were the same as those found in the modelling of the overall homicide series. The outlier-noise model for females incorporated three outliers.

The data for Sweden covered the years $1861-2013$ for the overall homicide rate $(n=153)$ and years 1869-2013 for gender specific homicide mortality ( $n=145)$. For the overall homicide mortality, an outlier-noise model of type $(0,1,1)$ with one transient type outlier turned to be 
adequate $(\mathrm{Q}(18)$; Sig. $=0.079)$. A model of type $(0,1,1)$ could also be accepted for male and female homicide series $(\mathrm{Q}(18)$; males Sig. $=0.386$, females Sig. $=0.435)$.

The Norwegian data covered the years 1861-2013. There were substantial gaps in gender specific homicide rates. As in Finland and Sweden, for overall homicide mortality, an outlier-noise model of type $(0,1,1)$, was adequate $(\mathrm{Q}(18)$; Sig. $=0.299)$. We detected and incorporated eight outliers into this model.

To achieve stationarity, required of the input series in the models, we differenced all alcohol consumption series.

Table 2 shows the estimated effects of the outliers detected in the homicide series. The types of outliers can be considered as particular cases of interventions or deterministic effects in a timeseries (Peña, 2010). In our case, almost all the outliers coincided with periods of extraordinary political, economic or alcohol legislation related events in history in the Nordic region (Table 2). In Finland, for example, the beginning of alcohol prohibition coincides with an estimated 5.0 increase in homicide mortality. In Sweden and Norway, estimated increases in homicide rates in 1873 were 0.53 and 0.44 . In both countries, the year coincided with the beginning of international economic depression. 
Table 2. Outliers detected in the homicide mortality series

\begin{tabular}{|c|c|c|c|c|c|}
\hline Country & Year & Type (1) & $\begin{array}{c}\text { Estimated } \\
\text { effect on } \\
\text { homicide rate }\end{array}$ & $\begin{array}{l}\text { Decay } \\
\text { factor }\end{array}$ & Description of significant historical events \\
\hline \multirow[t]{9}{*}{ Finland } & 1808 & Additive & 11.22 & & The 1808-1809 war, Russian occupation \\
\hline & 1905 & Level Shift & 2.13 & & The 1905 revolution, followed by the second period of Russification \\
\hline & 1915 & Transient & -2 & 0.87 & Beginning of WWI, restrictions in alcohol retail sales and civil liberties \\
\hline & 1917 & Level Shift & 4.45 & & The 1917 Russian revolutions, political turbulence \\
\hline & 1918 & Additive & 52.43 & & The Finnish civil war \\
\hline & 1919 & Additive & 5.04 & & The beginning of alcohol prohibition \\
\hline & 1933 & Innovational & -2.31 & & The end of alcohol prohibition \\
\hline & 1934 & Level Shift & -3.82 & & \\
\hline & 1949 & Level Shift & -1.81 & & The end of the "Years of Danger" after WWII \\
\hline Sweden & 1873 & Transient & 0.53 & 0.73 & Beginning of an international economic depression \\
\hline \multirow[t]{8}{*}{ Norway } & 1873 & Transient & 0.44 & 0.71 & Beginning of an international economic depression \\
\hline & 1903 & Additive & -0.31 & & \\
\hline & 1907 & Additive & -0.33 & & \\
\hline & 1939 & Additive & -0.39 & & \\
\hline & 1943 & Additive & 0.61 & & German occupation, WWII \\
\hline & 1944 & Additive & 1.1 & & German occupation, WWII \\
\hline & 1945 & Additive & 1.07 & & German occupation, WWII \\
\hline & 2011 & Additive & 0.68 & & The Utøya massacre \\
\hline
\end{tabular}

(1) For definitions of types of outliers, see Peña, 2010.

Table 3 shows the estimated impacts of annual changes in alcohol consumption on changes in homicide rates. In Finland, the model estimation showed a statistically significant association between alcohol consumption and overall homicide mortality rate for the period 1802-2013. The estimated impact of alcohol consumption was $0.10(\mathrm{p}<0.02)$ meaning that an increase of one litre in the per capita consumption of pure alcohol corresponds to a mean increase of 0.1 in the homicide mortality rate. (Because of the problems concerning the Finnish consumption data of 1920-1932, we also did the analysis controlling the effect of these years by defining the years as additive 
outliers. The excluding of the prohibition years did not change the estimated impact (Table 3).) The estimated impact on male mortality was $0.19(\mathrm{p}<0.02)$, on female mortality no impact was found. In Sweden, we observed a statistically discernible impact of $0.09(\mathrm{p}<0.03)$ on male homicide mortality but none on overall or female mortality. In Norway, we found no evidence of a statistical relationship between alcohol consumption and overall homicide mortality. The impact coefficient of Finnish males (years 1802-2013) was about twice as high as that of Swedish males (years 18692013) (Table 3). However, the average homicide mortality rate has been in Finland manifold compared to that in Sweden. If the coefficients of males are divided by the average male homicide mortality rates, we see that the relative effect of a unit change in alcohol consumption has in fact been higher in Sweden (7.7\%) than in Finland (3.4\%) (the average homicide mortality rates were calculated without the detected outliers).

Table 3. Total alcohol consumption and homicide mortality in Finland, Sweden, and Norway. Transfer function-noise models

\begin{tabular}{|c|c|c|c|c|c|}
\hline Country & $\begin{array}{l}\text { Type of } \\
\text { the outlier-noise } \\
\text { ARIMA model }(\mathrm{p}, \mathrm{d}, \mathrm{q})\end{array}$ & $\begin{array}{l}\text { Alcohol } \\
\text { consumption } \\
\text { estimate }\end{array}$ & $\begin{array}{l}\text { SE of } \\
\text { estimate }\end{array}$ & Sig. & $\begin{array}{l}\text { Q(lag 18) } \\
\text { Sig. (1) }\end{array}$ \\
\hline \multicolumn{6}{|l|}{ FINLAND } \\
\hline Homicide overall 1802-2013 & $0,1,1$ & 0.100 & 0.042 & 0.019 & 0.407 \\
\hline $\begin{array}{l}\text { Homicide overall 1802-2013 } \\
(\text { excl. 1920-1932) (2) }\end{array}$ & $0,1,1$ & 0.102 & 0.040 & 0.012 & 0.587 \\
\hline Homicide males $1802-2013$ & $0,1,1$ & 0.194 & 0.080 & 0.016 & 0.946 \\
\hline Homicide females 1802-2013 & $0,1,1$ & -0.001 & 0.023 & 0.959 & 0.303 \\
\hline \multicolumn{6}{|l|}{ SWEDEN } \\
\hline Homicide overall 1861-2013 & $0,1,1$ & 0.039 & 0.024 & 0.108 & 0.099 \\
\hline Homicide males 1869-2013 & $0,1,1$ & 0.091 & 0.041 & 0.026 & 0.382 \\
\hline Homicide females 1869-2013 & $0,1,1$ & 0.030 & 0.021 & 0.151 & 0.463 \\
\hline \multicolumn{6}{|l|}{ NORWAY } \\
\hline Homicide overall 1861-2013 & $0,1,1$ & -0.039 & 0.035 & 0.272 & 0.299 \\
\hline & & & & & \\
\hline
\end{tabular}

(1) Ljung-Box Q-test for residual autocorrelation.

(2) 1920-1932 defined as additive outliers 
In an earlier study covering the post-Second World War period Rossow (2001) found statistically significant impacts on male homicide mortality in all three Nordic countries for 1951-1995. According to her study, the Finnish alcohol-homicide association was not exceptionally strong in the Nordic context. Our results differed substantially from those of Rossow (2001). To test if differences in the specification of the models and in the way outlying observations were handled could explain the divergent results, we also estimated semilogaritmic models for male homicide mortality using the time period (1951-2013) for which data were available for all three countries and which corresponded largely to that in Rossow's study. In this analysis, we found a statistically significant alcohol consumption-male homicide mortality association only in Finland (Finland: 0.13, sig=0.001, Norway: 0.06 , sig=0.62, Sweden: 0.12 , sig=0.21).

For Finland, we also tested the time invariance of the association between alcohol consumption and homicide levels in three sub-periods based on political history: two of them could be described as eras of peaceful socio-political development, one as an era of violent crises (Rasila et al., 1977). The first era covered the years 1802-1899, ending at the constitutional crisis with Russia. The second period 1900-1948 included the gaining of independence, followed by a civil war, the politically and socially turbulent 1920s and 1930s and the Second World War. The last period started from 1948, which can be considered as the beginning of peacetime conditions after the war (Rasila et al., 1977) (Table 4). 
Table 4. Total alcohol consumption and homicide mortality in Finland. Transfer function-noise models for 1802-1899, 1900-1948, and 1949-2013

\begin{tabular}{|l|c|c|c|c|c|}
\hline & $\begin{array}{c}\text { Type of } \\
\text { the outlier-noise } \\
\text { ARIMA model } \\
\text { (p,d,q) }\end{array}$ & $\begin{array}{c}\text { Alcohol } \\
\text { consumption } \\
\text { estimate }\end{array}$ & estimate & & Q(lag 18) \\
\hline Homicide total & $0,1,1$ & & & \\
\hline $1802-1899$ & $0,1,0$ & $\mathbf{0 . 0 9 7}$ & 0.046 & 0.036 & 0.806 \\
\hline $1900-1948$ & $0,1,0$ & 0.781 & 0.556 & 0.168 & 0.508 \\
\hline $1900-1948$ & 0.719 & 0.542 & 0.195 & 0.927 \\
\hline (excl. 1920-1932)(2) & $0,1,1$ & $\mathbf{0 . 2 6 5}$ & 0.095 & 0.007 & 0.864 \\
\hline $1949-2013$ & & & & & \\
\hline
\end{tabular}

(1) Ljung-Box Q-test for residual autocorrelation.

(2) 1920-1932 defined as additive outliers

We found a statistically significant association between alcohol consumption and homicide mortality in the first $0.10(\mathrm{p}<0.04)$ and third period $0.27(\mathrm{p}<0.01)$, but not in the second period. Controlling the effect of the prohibition years by defining the years 1920-1932 as additive outliers did not change the result (Table 4).

\section{Discussion}

In this study, we have assessed the association between changes in annual alcohol consumption and homicide mortality in Finland, Sweden and Norway from the early 19th century to 2013. Our study has a substantially longer time frame than earlier Nordic studies, and covers the change in all three countries from pre-industrial to post-industrial societies (Lenke, 1990; Hauge, 1991; Norström, 1998; Skog and Björk, 1998; Rossow, 2001; Sirén, 2002). Moreover, we have taken into account the existence of possible outlying observations, those years of exceptionally high or low numbers of homicides, in our analysis. Failure to do this would probably have distorted the estimation outcome.

\section{Limitations}


This study has a number of limitations. We have had to use proxies (alcohol-related mortality, intoxication arrests, and confiscated illegal alcohol) in Finland to measure the alcohol consumption of 1802-1889 and 1920-1932. Although we believe that these proxies are relatively reliable indicators of consumption changes further research is needed to ascertain their applicability. The official consumption statistics of all three Nordic countries have their limitations, too, because they measure registered retail consumption and the volume of unregistered consumption may vary considerably over time. Also, in the time-series analysis our division of Finnish data into three nonoverlapping sub-periods is a relatively crude test of the time invariance of the alcohol consumptionhomicide rate association.

An additional limitation is that in this analysis we have not studied possible confounding variables that would be important to control for in any individual level analysis. Long-term sociodemographic variation in both alcohol consumption and homicide mortality (changes in gender, age and socioeconomic structure as well as the role of substance abuse) may have substantial effect on how the association between consumption and homicide mortality works.

\section{Main findings}

Our results indicate that homicide mortality has been most responsive to changes in the total alcohol consumption in Finland, and least responsive in Norway. We found for Finland a statistically significant impact of annual changes in per capita alcohol consumption on overall and male homicide mortality (1802-2013). In Sweden, we found a statistically significant impact on male homicide mortality (1869-2013) but none on female or overall (1861-2013) mortality. In Norway, we found no impact on overall homicide mortality (1861-2013). Because of the gaps in the Norwegian gendered homicide mortality data, we could not analyze the association separately for males and females for the whole period. However, our additional analysis on male mortality in 1951-2013 included also Norway. The additional analysis showed a statistically significant impact on male homicide mortality only in Finland. 
The results depart from earlier Scandinavian studies, which have found significant associations between alcohol consumption and homicide levels in Sweden for overall and in Norway for male homicide mortality (Lenke, 1990; Norström, 1998; Rossow, 2001). They also differ from what could have been expected on the basis of Rossow’s (2001) analysis of the years 1951-1995.

We think that one reason for divergent results are our longer time-series. The association between alcohol consumption and homicide mortality is not necessarily invariant over time. Also, the results of the analysis of the three sub-periods of our Finnish data suggest this. When we divided the Finnish data into three periods on the basis of Finland's political history, we found a statistically significant impact of annual per capita alcohol consumption changes on the overall homicide mortality in the first and third periods which could be described as peacetime eras, but none in the second period which included severe and multiple political and social crises. (The second period included also a fourteen-year prohibition and the alcohol consumption statistics of these years are not as reliable as those of the peacetime eras are. However, controlling the effect of the prohibition years and their statistics by defining the years 1920-1932 as additive outliers did not change the result.)

The divergent results of our study and the earlier ones can also be partly explained by differences in the specification of the models and in the way outlying observations are handled. Especially the analysis on male mortality of 1951-2013 suggests this. The period corresponded largely to that used by Rossow in her study (2001) and it is improbable that the different time frame could explain the differences in this case. In addition, the consumption data used for this period is fully comparable in all three countries.

All this highlights the fact that in weak statistical associations (like the one between alcohol consumption and homicide rates) the results of time-series modelling are sensitive to model specifications and properties of data (covered time span, presence of influential observations etc.). It should also be noted that in Norway the annual number of homicides has been very small 
throughout the last few centuries, making it difficult to find a statistically discernible association between the total alcohol consumption and homicide mortality.

However, our results are in line with those findings which indicate that alcohol has a more central role in Finnish homicides than elsewhere in the Nordic region (Verkko, 1951; Kivivuori and Lehti, 2011; Granath et al., 2011). Thus, the results give support to the thesis that the possible effect of alcohol consumption on violent crime at the community level exists mainly in countries with the most explosive drinking patterns (see Lenke, 1990; Rossow, 2001; Bye, 2012). This seems to be true even in a group of countries (like in our case) where the differences in drinking patterns are relatively small in the global context. Moreover, changes in the total alcohol consumption in the Nordic countries seem to have had during the last two hundred years greater relevance in relation to male than female homicide mortality (see also Rossow, 2001).

Based on our study, in spite of the statistically discernible association between total consumption and male homicide mortality in Finland and Sweden, one cannot conclude that the regulation of total alcohol consumption would be an efficient general tool for preventing homicides even in Scandinavia. Our results support, however, the findings that in Finland, alcohol consumption has had during the last two centuries and has even today a more central role in violent crime than in Sweden or Norway. Although in terms of mortality levels and level changes, wars and social crises have dominated homicide mortality in Finland during the last two centuries (Ylikangas, 1976; Kivivuori and Lehti, 2011), in normal peacetime conditions, i.e. before 1900 and after 1948, there seem to have been a close positive association between total alcohol consumption and overall male homicide mortality rates. The strength of this association has been much weaker in Sweden and apparently absent in Norway. This finding suggests that alcohol may indeed be part of the explanation of the persistently higher homicide mortality in Finland that in other parts of Scandinavia.

\section{Funding}


This study was funded by the Institute of Criminology and Legal Policy of the University of Helsinki.

\section{Acknowledgements}

We thank professors Janne Kivivuori and Mikko Aaltonen and two anonymous referees for their valuable criticism and advice.

\section{References}

Aebi MF and Linde A (2012) Crime Trends in Western Europe according to Official Statistics from 1990 to 2007. In: van Dijk J, Tseloni A and Farrell G (eds) The International Crime Drop. New Trends in Research. New York: Palgrave Macmillan, pp 37-75.

Arnberg J and Lord S (2009) Swedish Alcohol Policy - An Effective Policy? Stockholm: The Swedish Retail Institute HUI. Retrieved from www.brewersofeurope.org/uploads/mycmsfiles/documents/archives/hui_2009_swedish_alcohol_policy_study.pdf, Archived at www.webcitation.org/6pNRR5PJ1 on March 31st, 2017.

Bye EK (2007) Alcohol and Violence. Use of possible confounders in a time-series analysis. Addiction 102: 369-376.

Bye EK (2008) Alcohol and homicide in Eastern Europe: A time series analysis of six countries. Homicide Studies 12: 7-27.

Bye EK (2012) Alcohol and Homicide in Europe. In: Liem M and Pridemore WA (eds) Handbook in European Homicide Research. New York: Springer, pp 231-246.

Drap i Norge i perioden 2004-2009 (2010) Norges offentlige utredninger 2010:3. Oslo:

Departementenes servicesenter.

Drogutvecklingen i Sverige 2010 (2010) CAN rapport 125. Stockholm: Centralförbundet för alkohol- och narkotikaupplysning.

Drogutvecklingen i Sverige 2014 (2014) CAN rapport 144. Stockholm: Centralförbundet för alkohol- och narkotikaupplysning.

Gmel G, Rehm J and Frick U (2001) Methodological Approaches to Conducting Pooled CrossSectional Time Series Analysis: The Example of the Association between All-Cause Mortality and per capita Alcohol Consumption for Men in 15 European States. European Addiction Research 7: $128-137$. 
Gómez V and Maravall A (2010) Automatic Modelling Methods for Univariate Series. In: Peña, D Tiao GC and Tsay RS (eds) A Course in Time Series Analysis. New York: John Wiley \& Sons, pp 171-201.

Granath S, Hagstedt J, Kivivuori J, Lehti M, Ganpat S, Liem M and Nieuwbeerta P (2011) Homicide in Finland, the Netherlands and Sweden. A First Study on the European Homicide Monitor Data. The Swedish National Council for Crime Prevention Research Report 2011:15. Stockholm: Brottsförebyggande rådet.

Hauge R (1991) Alkohol og voldskriminalitet. Nordisk Tidsskrift for Kriminalvidenskab 78: $145-163$.

von Hofer H (2011) Brott och straff $i$ Sverige. Historisk kriminalstatistik 1750-2010. Diagram, tabeller och kommentarer. Stockholm: Stockholms universitet.

von Hofer H and Lappi-Seppälä T (2014) The Development of Crime in Light of Finnish and Swedish Criminal Justice Statistics, Circa 1750-2010. European Journal of Criminology 11: 169194.

Ignatius KEF (1885) Statistiska bidrag till belysande af bränvinskonsumptionen i Finland. Bidrag till kännedom af Finlands Natur och Folk 40. Helsingfors: ?.

Jääskeläinen M (2011) Unpublished data retrieved from Ms. Marke Jääskeläinen at National Institute for Health and Welfare (FI), 28.10.2011. The data are stored in the Institute of Criminology and Legal policy, Unioninkatu 40, Helsinki, Finland.

Jansson A (1998) From Swords to Sorrow. Homicide and Suicide in Early Modern Stockholm. Acta Universitatis Stockholmiensis Stockholm Studies in Economic History 30. Stockholm: Almqvist \& Wiksell.

Kaartinen A (2012) Kieltolaki ei kuivattanut Suomea. Duodecim 127: 2445-2452.

Kaspersson M (2000) Dödligt våld i Stockholm på 1500-, 1700- och 1900-talet. Stockholms universitet, Kriminologiska institutionen, Avhandlingsserie 4. Stockholm: Stockholms universitet, Kriminologiska institutionen.

Kivivuori J and Lehti M (2011). Homicide in Finland and Sweden. In: Tonry M and Lappi-Seppälä T (eds) Crime and Justice in Scandinavia. Crime and Justice, Vol. 40. Chicago: The University of Chicago Press, pp 109-198.

Koskivirta A (2014) Kuolemansyyn selvittäminen. Lainsäädäntö, vastuuviranomaiset ja asiakirjaaineistot Suomessa 1600-luvulta nykyaikaan. Genos 85: 194-209.

Kuntsche E, Rehm J and Gmel G (2004) Characteristics of binge drinkers in Europe. Social Science \& Medicine 59: 113-127.

Lappi-Seppälä T and Lehti M (2015) Cross-comparative perspectives on global homicide trends. In: Tonry M (ed), Why Crime Rates Fall, and Why They Don't. Crime and Justice, Vol. 43. Chicago: University of Chicago Press, pp 135-230. 
Lehti M (2001) Väkivallan hyökyaalto. 1900-luvun alkuvuosikymmenten henkirikollisuus Suomessa ja Luoteis-Virossa. Oikeuspoliittisen tutkimuslaitoksen julkaisuja 178. Helsinki: Oikeuspoliittinen tutkimuslaitos.

Lehti M (2017) Henkirikoskatsaus 2017. Kriminologian ja oikeuspolitiikan instituutin katsauksia 19/2017. Helsinki: Krimo.

Lehti M and Kivivuori J (2011) Homicide in Finland. In: Liem M and Pridemore WA (eds) Handbook in European Homicide Research. New York: Springer, pp 391-404.

Lenke L (1990) Alcohol and Criminal Violence. Time Series Analyses in a Comparative Perspective. Stockholm: Almqvist \& Wicksell.

Lindqvist P (1986) Criminal homicide in northern Sweden 1970-1981: alcohol intoxication, alcohol abuse and mental disease. International Journal of Law and Psychiatry 8: 19-37.

Mäkelä K (1986) Attitudes towards Drinking and Drunkenness in Four Scandinavian Countries. Annals of the New York Academy of Sciences 472: 21-32.

Mäkelä P, Fonager K, Hibell B, Nordlund S, Sabroe S and Simpura J (2001) Episodic heavy drinking in four Nordic countries: a comparative study. Addiction 96: 1575-1588.

Mills TC (1990) Time series techniques for economists. Cambridge: Cambridge University Press.

Nasjonal drapsoversikt 2013 (2014). Oslo: Kripos.

Norström T (1998) Effects on criminal violence of different beverage types and private and public drinking. Addiction 93: 689-699.

Österberg E (2000) Unrecorded alcohol consumption in Finland in the 1990s. Contemporary Drug Problems 27: 271-299.

Päihdetilastollinen vuosikirja 2010 (2010) Alkoholi ja huumeet. Suomen virallinen tilasto, Sosiaaliturva 2010. Helsinki: Terveyden ja hyvinvoinnin laitos.

Parker RN and Cartmill RS (1998) Alcohol and Homicide in the United States 1934-1995 - Or One Reason Why U.S. Rates of Violence May Be Going Down. The Journal of Criminal Law and Criminology 88: 1369-1398.

Peña D (2010) Outliers, Influential Observations, and Missing Data. In: Peña, D, Tiao GC and Tsay RS (eds) A Course in Time Series Analysis. New York: John Wiley \& Sons, pp 136-170.

Pernanen K (1981) Theoretical Aspects of the Relationship between Alcohol Use and Crime. In: Collins JJ (ed) Drinking and Crime. New York: The Guilford Press, pp 1-69.

Pridemore WA (2002) Vodka and Violence: Alcohol Consumption and Homicide Rates in Russia. American Journal of Public Health 9: 1921-1930.

Pridemore WA and Chamlin MB (2006) A time-series analysis of the impact of heavy drinking on homicide and suicide mortality in Russia, 1956-2002. Addiction 101: 1719-1729. 
Rasila V, Jutikkala E and Kulha KK (1977) Suomen polittinen historia 1809-1975. 2. osa. Porvoo: WSOY.

Rasinaho K (2006) Alkoholin salakauppa Helsingissä vuosina 1919-1932. In: Peltonen M, Kilpiö K and Kuusi H (eds) Alkoholin vuosisata. Suomalaisten alkoholiolojen käänteitä 1900-luvulla. Helsinki: SKS, pp 17-85.

Rehm J and Gmel G (2001) Aggregate time series regression in the field of alcohol. Addiction 96: 945-954.

Rossow I (2001) Alcohol and homicide: a cross-cultural comparison of the relationship in 14 European countries. Addiction 96: S77-S92.

Rossow I (2004) Alcohol consumption and homicides in Canada 1950-1999. Contemporary Drug Problems 31: 541-559.

Rying M (2000) Dödligt våld i Sverige 1990-1998. En deskriptiv studie. Stockholm: Stockholms universitet.

Sirén K (1995) Brotssligheten i Finland i slutet av 1700- och början av 1800-talet. Historisk Tidskrift för Finland 80: 39-63.

Sirén R (2002) Trends in Assault: On the Relationship between the Assault Rate and Selected Social Indicators in Post-War Finland. Journal of Scandinavian Studies in Criminology and Crime Prevention. 3: 22-49.

Skog O-J and Björk E (1998) Alkohol og voldskriminalitet. En analyse av utviklingen i Norge 1931-82. Nordisk Tidsskrift for Kriminalvidenskab 75: 1-23.

Spierenburg P (2012) Long-Term Historical Trends of Homicide in Europe. In: Liem M and Pridemore WA (eds) Handbook in European Homicide Research. New York: Springer, pp 25-38.

Statistics Norway (2016) Alcoholomsetning. Oslo: Statistics Norway. Retrieved from www.ssb.no/statistikkbanken/selectvarval/Define.asp?subjectcode=\&ProductId=\&MainTable=Alko holForbruk\&nvl=\&PLanguage=0\&nyTmpVar=true \&CMSSubjectArea=varehandel-ogtjenesteyting \&KortNavnWeb=alkohol\&StatVariant $=\&$ checked $=$ true, Archived at www.webcitation.org/6pNQTW57b on March 31st, 2017.

Suomen tilastollinen vuosikirja 1916 (1916). Helsinki: Tilastollinen päätoimisto.

Suomen tilastollinen vuosikirja 1921 (1921). Helsinki: Tilastollinen päätoimisto.

Suomen taloushistoria 3 (1983). Historiallinen tilasto. Helsinki: Tammi.

Turpeinen O (1975) Viinaan kuolleet Suomessa 1802-77. Alkoholipoliittisen tutkimuslaitoksen tutkimusseloste 90. Helsinki: Alkoholipoliittinen tutkimuslaitos.

Turpeinen O (1977) Viinaan kuolleet Suomessa 1878-1917. Alkoholipoliittisen tutkimuslaitoksen tutkimusseloste 110. Helsinki.

Varis T and Virtanen S (2016) Alkoholijuomien kulutus 2015. Helsinki: THL. 
Verkko V (1948) Maailman vanhin väkivaltatilasto. Taulustolaitoksen 200-vuotismuiston johdosta. Helsinki: Valtioneuvoston kirjapaino.

Verkko V (1951) Homicides and suicides in Finland and their dependence on national character. Scandinavian studies in sociology 3. Köbenhavn: G. E. C. Gads Forlag.

Vuorela M (2014) Prokuraattorin kertomukset kriminologian lähteenä. Oikeuspoliittisen tutkimuslaitoksen tutkimustiedonantoja 127. Helsinki: Oikeuspoliittinen tutkimuslaitos.

Ylikangas H (1976) Puukkojunkkareitten esiinmarssi. Väkivaltarikollisuus Etelä-Pohjanmaalla 1790-1825. Keuruu: Otava. 